\title{
MATHEMATICS COMMUNICATION MISTAKES IN SOLVING HOTS PROBLEMS
}

\author{
Lelly Nur Rachmawati, Yus Mochamad Cholily, Zukhrufurrohmah* \\ Universitas Muhammdiyah Malang, Indonesia
}

\begin{tabular}{l}
\hline \hline Article Info \\
\hline Article history: \\
Received Aug 8, 2020 \\
Revised Jan 10, 2021 \\
Accepted Jan 11, 2021 \\
\hline
\end{tabular}

\section{Keywords:}

High Order Thinking Skill, Mathematical Communication, Mathematics Mistakes

\begin{abstract}
Student mistakes in communicating mathematical ideas are still widely practiced. Therefore, it is essential to analyze students' mathematical communication errors in solving mathematical problems so that learning planning can be better. This study aims to describe students' mathematics communication errors in solving higher-order thinking skills in linear algebra and matrix subject. The type of research is a qualitative descriptive study. They were 155 students as subject research. The data analysis started by collecting students' answers and then grouped them according to mathematics communication skills criteria. Later identified and analyzed the errors made by students of each mathematics communication criteria. The results showed that mathematical communication errors on the indicators of writing mathematical situations were concept errors and principle errors. The declaring idea's mathematical communication error is a concept error, a principle error, and an operation error. Furthermore, mathematical communication errors on the indicator state that solving-problem using the language itself is a concept error and operator error.
\end{abstract}

Copyright $(2021$ IKIP Siliwangi. All rights reserved.

\section{Corresponding Author:}

Zukhrufurrohmah,

Department of Mathematics Education,

Faculty of Teacher Training and Education

Universitas Muhammdiyah Malang,

Jl. Raya Tlogomas 246 Malang, East Java 65144, Indonesia

Email: zukhrufurrohmah@umm.ac.id

\section{How to Cite:}

Rachmawati, L. N., Cholily, Y. M., \& Zukhrufurrohmah, Z. (2021). Mathematics communication mistakes in solving HOTS problems. Infinity, 10(1), 69-80.

\section{INTRODUCTION}

Learning and communication are integral parts. Kleden (2016) emphasized that in learning activities there was an exchange of information in the form of knowledge and experience between lecturers and students, students and students, also between students and teaching materials, so mathematical communication skills were very much needed. Firdaus and Aini (2019) added that learning activities carried out by students were not limited to memorizing formulas and mastering calculations, but also learning through mathematical communication. Kleden (2016) emphasized that with excellent mathematics communication, students can convey ideas or thoughts appropriately to convince themselves and others. The importance of student mathematical communication is currently a problem that must be considered (Angraini, 2019; Argarini, Yazidah, \& Kurniawati, 2020; Astuti \& 
Leonard, 2015; Nuraida \& Amam, 2019; Prabawanto, 2019; Rosita, Nopriana, \& Silvia, 2019). Therefore, the development of students' mathematics communication skills in problem-solving must master at the lecture level (Fatimah, 2012). It will be useful in social life and good problem-solving results for students (Ruswana, 2019).

Excellent communication skills are essential for students because, through symbolic language, students can communicate mathematically accurately and accurately (Novianti, 2017). Student's ability to solve problems can be influenced by students' written mathematics communication skills through their answer sheets (Ardina \& Sa'dijah, 2016). Umar (2012) emphasized that communication and problem-solving skills are related and essential to have so that mistakes not occurred. Therefore, it is crucial to develop student mathematics communication.

The importance of having mathematics communication skills is not in line with the facts which show that many students make mistakes in communicating their ideas (Pratiwi, 2015). Most of them do not master the concepts but only memorize them (Ruswana, 2019). Students make a lot of mistakes in mathematics communication skills. Therefore mathematics communication conducted through tests will determine the students' ability to master the material (Subekti et al., 2016). Based on this information, mathematics communication skills are related to mathematical errors made by students.

According to Ardiawan (2015), mathematics errors are systematic errors that occur when the answers are written differently from the real solutions. Firdaus (2019) said that there were some mistakes when solving Matrices about understanding the question of the story, using formulas and concepts, and doing calculations. Besides, Wijaya and Masriyah (2013) said that there were several types of mistakes made, namely concept errors, principle errors, and operating errors. Concept errors are caused by students when misinterpreting or using terms so they cannot understand a given material/problem (Widodo, 2013; Widodo et al., 2020). Principal error is a mistake made because of the inability of students to connect/link several concepts in the right relationship (Astuty \& Wijayanti, 2013). Then, Astuty and Wijayanti (2013) said the operation error was an error made due to incorrect calculation. At the same time, Zukhrufurrohmah and Kusumawardana (2019) research states that the types of mathematical errors can be in the form of skills, concepts, and techniques. But in this study, the mathematics errors that be analyzed were concept errors, principle errors, and operating errors.

Agree with Asviangga et al. (2018) that one of the problems that can lead to mathematics communication skills is a matter of high-level thinking. Rahayuningsih and Jayanti (2019) said that improving the quality of learning can obtain by solving HigherOrder Thinking Skills (HOTS). Thus when students do problem-solving activities can use a different approach, it will be possible to do so that a high-level thinking process occurs (Rahayuningsih \& Jayanti, 2019). HOTS questions are questions that require you to use higher-order thinking skills (Pratiwi et al., 2017). The aspects of the HOTS problem are analyzing, evaluating, and creating (Rahayuningsih \& Jayanti, 2019). Based on some of these aspects in this study HOTS Problem indicators in measuring mathematics communication are students can: 1) analyze the mathematical situation by breaking down the information obtained; 2) evaluate by testing against an idea by the procedure to clarify a statement, and 3) create with writing a summary or theory to conclude.

According to the explanation, this researcher is interested in describing mathematics communication errors that students have when completing HOTS Questions in Linear Algebra and Matrix subjects. 


\section{METHOD}

This research is qualitative descriptive research aiming to describe the written mathematics communication errors made by students in completing the HOTS problem on matrix material. The study begins by conducting field observations with the data obtained is that students make some mistakes in conveying the idea of solving a given problem. Based on this problem, instruments were then arranged in the form of HOTS-style test questions to lead to errors and mathematics communication of students. The test questions were validated by two mathematics education lecturers who experts in teaching Linear Algebra and Matrix subjects. The test was given to the students through the lms.umm.ac.id platform. Students collect their answers by uploading handwritten photos or sending typed results to lms.umm.ac.id through their respective accounts. HOTS problems that valid were served in Table 1.

Table 1. Research instruments

\begin{tabular}{|c|c|c|c|c|}
\hline & Number of Question & $\begin{array}{c}\text { HOTS } \\
\text { Aspect }\end{array}$ & $\begin{array}{l}\text { Mathematics communication } \\
\text { Indicator on the answer to } \\
\text { the problem }\end{array}$ & $\begin{array}{l}\text { Mathematical } \\
\text { Error that } \\
\text { Appears in } \\
\text { Problem }\end{array}$ \\
\hline \multirow[t]{3}{*}{1.} & $\begin{array}{l}\text { Find matrix } A \text {, matrix } B, \\
\text { matrix } C \text {, so } A C=B C \\
\text { and } A \neq B !\end{array}$ & Analyze & $\begin{array}{l}\text { Understanding the } \\
\text { mathematical situation clearly, } \\
\text { students write that the matrix } \\
A C=B C \text { and matrix } A \text { are } \\
\text { different from matrix } B\end{array}$ & $\begin{array}{l}\text { Concept errors, } \\
\text { principle errors } \\
\text { and operating } \\
\text { errors }\end{array}$ \\
\hline & & Evaluate & $\begin{array}{l}\text { Writing ideas clearly, students } \\
\text { will test by multiplying the two } \\
\text { matrices to find out whether } \\
A C=B C \text { and served matrix } A \\
\text { are different from matrix } B\end{array}$ & $\begin{array}{l}\text { Concept errors, } \\
\text { principle errors } \\
\text { and operating } \\
\text { errors }\end{array}$ \\
\hline & & Create & $\begin{array}{l}\text { Stating the results of problem- } \\
\text { solving using their language, } \\
\text { students write the conclusion } \\
\text { that matrices } \mathrm{A} \text { and } \mathrm{B} \text { are } \\
\text { different matrices so that } A C= \\
B C \text { and } A \text { are different from } B\end{array}$ & $\begin{array}{l}\text { Concept errors, } \\
\text { principle errors } \\
\text { and operating } \\
\text { errors }\end{array}$ \\
\hline & $\begin{array}{l}\text { Suppose there is a } \\
\text { matrix } A \text { with the } \\
\text { following components: } \\
A=\left[\begin{array}{llll}0 & 1 & 0 & 0 \\
0 & 0 & 1 & 0 \\
0 & 0 & 0 & 1 \\
0 & 0 & 0 & 0\end{array}\right]\end{array}$ & Analyze & $\begin{array}{l}\text { By understanding the } \\
\text { mathematical situation clearly, } \\
\text { students write down the } \\
\text { information obtained from } \\
\text { matrix } A, \text { matrix } A^{2}=A A, \\
\text { matrix } A^{3}=A A A \text { and } \\
\qquad A^{n}=\underbrace{A A \ldots A}_{\text {as many as } n}\end{array}$ & $\begin{array}{l}\text { Concept errors, } \\
\text { principle errors } \\
\text { and operating } \\
\text { errors }\end{array}$ \\
\hline & $A^{3}=A A A$, and & Evaluate & $\begin{array}{l}\text { Writing out ideas clearly, } \\
\text { students test by calculating the } \\
\text { matrices } A^{2} \text { and } A^{3} \text { whether } \\
\text { they produce a zero-matrix or } \\
\text { not, then clarify that the results }\end{array}$ & $\begin{array}{l}\text { Concept errors, } \\
\text { principle errors } \\
\text { and operating } \\
\text { errors }\end{array}$ \\
\hline
\end{tabular}




\begin{tabular}{|c|c|c|c|}
\hline Number of Question & $\begin{array}{l}\text { HOTS } \\
\text { Aspect }\end{array}$ & $\begin{array}{c}\text { Mathematics communication } \\
\text { Indicator on the answer to } \\
\text { the problem }\end{array}$ & $\begin{array}{l}\text { Mathematical } \\
\text { Error that } \\
\text { Appears in } \\
\text { Problem }\end{array}$ \\
\hline $\begin{array}{l}A^{n}= \\
\underbrace{A A \ldots A}_{\text {as many as n }} \\
\text { Is it possible that } \\
A^{n} \text { produces a zero } \\
\text { matrix? Provide }\end{array}$ & & $\begin{array}{l}\text { of the matrix } A^{2} \text { and } A^{3} \text { are not } \\
\text { zero-matrices, and then test for } \\
\text { the student matrix } A^{n} \text { use each } \\
\text { idea to find out whether the } \\
\text { matrix } A^{n} \text { will produce a zero } \\
\text { matrix }\end{array}$ & \\
\hline $\begin{array}{l}\text { detailed explanations } \\
\text { of the answers! }\end{array}$ & Create & $\begin{array}{l}\text { Using their language, students } \\
\text { write the possibility of the } \\
\text { matrix } A^{n} \text { to produce a zero- } \\
\text { matrix }\end{array}$ & $\begin{array}{l}\text { Concept errors, } \\
\text { principle errors } \\
\text { and operating } \\
\text { errors }\end{array}$ \\
\hline
\end{tabular}

The result of 155 students work are grouped according to good mathematics communication skill or less mathematics communication skill. The good mathematics communication skills are given when students answer fulfill three indicators of mathematics communication. Otherwise, students have less mathematics communication skill.

Data analysis techniques in this study were carried out through 3 stages: data reduction, data presentation, and concluding. The data reduction stage is carried out by grouping the answers of the two questions based on similar answers into several types of the four classes. This is done to facilitate the analysis based on indicators that have been determined. Then the data obtained are presented in tables and diagrams. And the next step is to conclude the result based on data gathered.

\section{RESULTS AND DISCUSSION}

\subsection{Results}

Data obtained from the four classes were 155 student answers. Figure 1 shows that 148 students have less mathematics communication in the Question 1 or first question, and seven students who have excellent mathematics communication. Judging from the number of answers shows that mathematics communication possessed by students is still lacking. Only $4.5 \%$ of the total amount has excellent mathematics communication. It shows that students cannot communicate their ideas well so that they have difficulty in problem-solving.

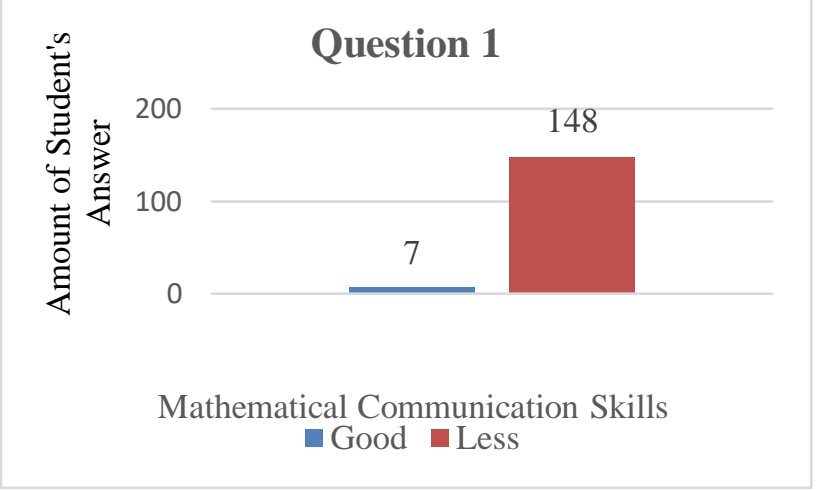

Figure 1. Number of mathematics communication questions 1 
Whereas in Figure 2, the number of answers to second question or Question 2 does not differ from Question 1. The number of students with communication is more or less compared to students with excellent communication. But for the second question, there is no difference with the distant numbers, namely 85 students with less mathematics communication and 70 students with excellent communication. It means that students are more able to communicate their ideas in the second question than the first question.

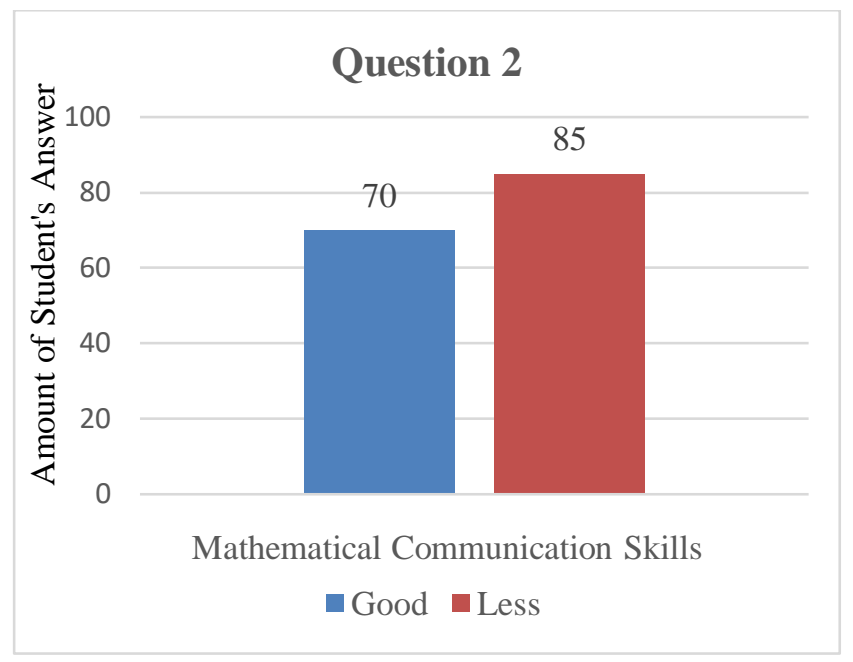

Figure 2. Number of mathematics communication questions 2

Figure 1 and Figure 2 shows that students with good mathematics communication skills are minimal. It can happen because students were making many mistakes when solving problems, such that it did not match the mathematics communication indicator. Table 2 shows that most students made mistakes when stating their problem-solving problems by using their language. These mistakes can be taken because students get used to calculating without looking back on the problem. Another possibility that causes students to have less mathematics communication skills understands the multiple matrices such that students cannot write their ideas clearly. The weakness of understanding the problems is also one of the factors that caused students to make mistakes to determine the solution steps. The percentages of each student's mathematics communication criteria were presented in Table 2.

Table 2. Percentage of mathematics communication of students each indicator

\begin{tabular}{cccccccc}
\hline \multirow{2}{*}{ No. } & \multirow{2}{*}{$\begin{array}{c}\text { Mathematics } \\
\text { communication indicator }\end{array}$} & \multicolumn{2}{c}{ Question 1 } & \multicolumn{2}{c}{ Question 2 } & \multicolumn{2}{c}{ Average } \\
\cline { 3 - 7 } & good & less & good & less & good & less \\
\hline 1 & $\begin{array}{c}\text { Understand the mathematical } \\
\text { situation clearly }\end{array}$ & $84.52 \%$ & $15.48 \%$ & $83.23 \%$ & $16.77 \%$ & $83.86 \%$ & $16.13 \%$ \\
\hline 2 & $\begin{array}{c}\text { Write ideas of problem- } \\
\text { solving clearly }\end{array}$ & $76.77 \%$ & $23.23 \%$ & $73.55 \%$ & $26.45 \%$ & $75.16 \%$ & $24.84 \%$ \\
\hline 3 & $\begin{array}{c}\text { State the results of problem- } \\
\text { solving using your language }\end{array}$ & $6.45 \%$ & $93.55 \%$ & $58.06 \%$ & $41.94 \%$ & $32.26 \%$ & $67.75 \%$ \\
\hline
\end{tabular}

Table 2 shows that not all students meet the three mathematics communication criteria in solving HOTS problems. The third criterion of mathematics communication, declare the answer to solving HOTS's problem using their language, obtain the most significant percentage of $93.55 \%$. This percentage is the highest compared to the other two 
indicators. It happens because students are incomplete in writing conclusions of problemsolving. The highest rate in the second question for the category lacking was also found in the indicator, stating the solving results using their language that is $41.94 \%$. Most students did not write the conclusions of the calculation that they obtain. Although students are good at understanding mathematical situations or writing their ideas, it did not mean that students' mathematics communication was excellent.

Each rate of mathematics communication skills showed that not all students fulfilled all criteria of mathematics communication. Students in problem-solving with problems may make mistakes by mathematics communication written owned. The mistakes made by students in completing Problems are presented in Table 3.

Table 3. Forms of student mathematical errors

\begin{tabular}{|c|c|c|c|}
\hline \multirow{2}{*}{$\begin{array}{l}\text { Mathematics } \\
\text { communication } \\
\text { indicator }\end{array}$} & \multicolumn{3}{|c|}{ Types of mistakes made by students } \\
\hline & Concept & Principle & Operation \\
\hline $\begin{array}{l}\text { Understand the } \\
\text { mathematical situation } \\
\text { clearly }\end{array}$ & $\begin{array}{l}\text { In Question } 1 \text {, it is } \\
\text { wrong to determine } \\
\text { matrix } A, B, C\end{array}$ & $\begin{array}{l}\text { In Problem } 2 \text {, the concept } \\
\text { of an identity matrix and } \\
\text { matrix multiplication is } \\
\text { wrong }\end{array}$ & Not found \\
\hline $\begin{array}{l}\text { Write ideas of problem- } \\
\text { solving clearly }\end{array}$ & $\begin{array}{l}\text { In Question } 2 \text {, it is } \\
\text { wrong to apply the } \\
\text { concept } \\
\text { multiplication to the } \\
A A \text { matrix }\end{array}$ & $\begin{array}{l}\text { In Question } 1 \text {, it is wrong to } \\
\text { use ideas, so there is no } \\
\text { relationship between the } \\
\text { matrix } A B C \\
\text { In Question } 2 \text { it is wrong to } \\
\text { form the matrix } A^{n} \text { because } \\
\text { it does not find a } \\
\text { relationship with the matrix } \\
A^{2} \text { and } A^{3}\end{array}$ & Not found \\
\hline $\begin{array}{l}\text { State the results of } \\
\text { problem-solving using } \\
\text { your language }\end{array}$ & $\begin{array}{l}\text { In Question } 1 \text {, it is } \\
\text { wrong to conclude } \\
\text { that } A C=B C \text {. } \\
\text { In Question } 2 \text {, it is } \\
\text { wrong to conclude } \\
\text { that } A^{n} \text { will probably } \\
\text { produce a zero-matrix }\end{array}$ & Not found & $\begin{array}{l}\text { In Question 1, it } \\
\text { was wrong to } \\
\text { calculate the } \\
2 x 2 \text { matrix } \\
\text { multiplication. }\end{array}$ \\
\hline
\end{tabular}

\subsubsection{Mathematical Errors when Understanding Mathematical Situations Clearly}

On the indicators of understanding the mathematical situation clearly, students made mistakes, namely misconceptions and principles, but did not make operational errors. In the second question, students did not make misconceptions when understanding mathematical situations. Students created a mistake in the first question. The mistake made by students were wrong in determining the A, B, C matrices. These errors resulted in students not getting $\mathrm{AC}=\mathrm{BC}$. The answers of students who make misconceptions when understanding the mathematical situation are clearly shown in Figure 3. Figure 3 shows that students only determine matrix $\mathrm{C}$ and then conclude that $\mathrm{AC}$ is the same as $\mathrm{AB}$, while matrix $\mathrm{A}$ and matrix $\mathrm{B}$ are not explained as components. 


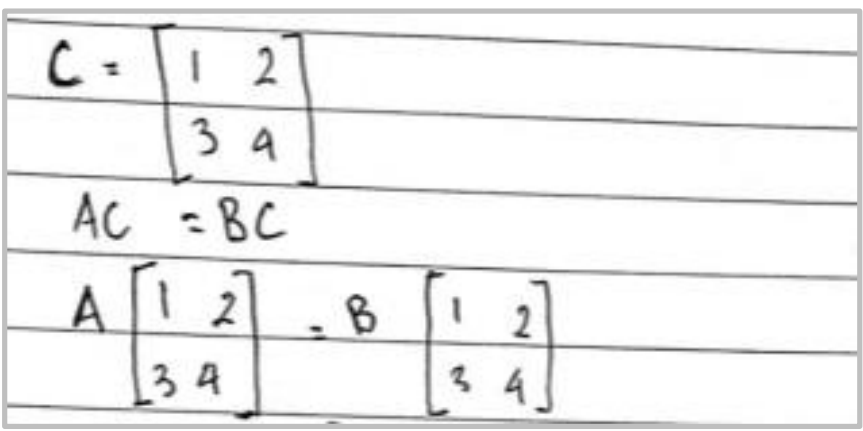

$$
\begin{aligned}
& C=\left[\begin{array}{ll}
1 & 2 \\
3 & 4
\end{array}\right] \\
& A C=B C \\
& A=\left[\begin{array}{ll}
1 & 2 \\
3 & 4
\end{array}\right]=B\left[\begin{array}{ll}
1 & 2 \\
3 & 4
\end{array}\right]
\end{aligned}
$$

Figure 3. Misconceptions when understanding mathematical situations in the first problem

Students make a principles mistake in the form of incorrectly linking the concept of the identity matrix and matrix multiplication. Figure 4 is the answer to students who earned a principles error when they did not understand the mathematical situation correctly. Students make a mistake when multiplying the matrix and stating that the matrix $\mathrm{A}^{2}$ is the identity matrix.

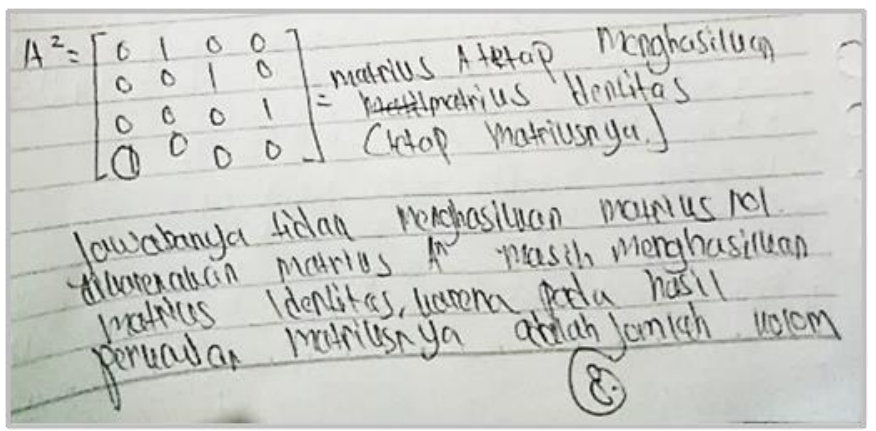

$A^{2}=\left[\begin{array}{llll}0 & 1 & 0 & 0 \\ 0 & 0 & 1 & 0 \\ 0 & 0 & 0 & 1 \\ 0 & 0 & 0 & 0\end{array}\right]=$ Matrix A still produces an identity matrix (fixed matrix). The answer is the matrices does not produce a zero matrix, because the matrix $A^{n}$ still produces an identity matrix because the multiplication result of the matrix is the number of columns.

Figure 4. Mistakes in principle when understanding mathematical situations clearly

\subsubsection{Mathematical Mistakes when Writing Out Problem-Solving Ideas Clearly}

Students make misconceptions, principles, and operations when writing problemsolving ideas on the second problem. But in the first question, no students made mathematical mistakes. In the second problem, students created a misconception, namely not applying the concept of multiplication to matrix A. Students wrote the conclusion that $\mathrm{A}^{\mathrm{n}}$ produced a null matrix, but did not test the multiplication against $\mathrm{A}^{4}$ matrix. Figure 5 shows students' mistakes, not doing the calculation concept of matrix A, so that they do not write ideas.

Ya, $A^{n}$ menghasillam matiiles 0
perijelosan: micallem $A^{4}=$ matriles 0
karem $A^{3}=\left[\begin{array}{llll}0 & 0 & 0 & 1 \\ 0 & 0 & 0 & 0 \\ 0 & 0 & 0 & 0 \\ 0 & 0 & 0 & 0\end{array}\right]$

Yes, $A^{n}$ yields a zero matrix
Explanation: Suppose $A^{4}=$ matrix 0
Because $A^{3}=\left[\begin{array}{llll}0 & 0 & 0 & 1 \\ 0 & 0 & 0 & 0 \\ 0 & 0 & 0 & 0 \\ 0 & 0 & 0 & 0\end{array}\right]$

Figure 5. Misconceptions when writing clear problem-solving ideas 
Students made a principles mistake in the second problem by not doing the multiplication concept on the matrix $\mathrm{A}^{3}$. Students only perform calculations on matrix $\mathrm{A}^{2}$ so that they do not find the relationship between the $\mathrm{A}^{2}$ and $\mathrm{A}^{3}$ matrices in finding the $\mathrm{A}^{\mathrm{n}}$ matrix. So, it concludes without checking whether $\mathrm{A}^{\mathrm{n}}$ yields a null matrix (Figure 6).
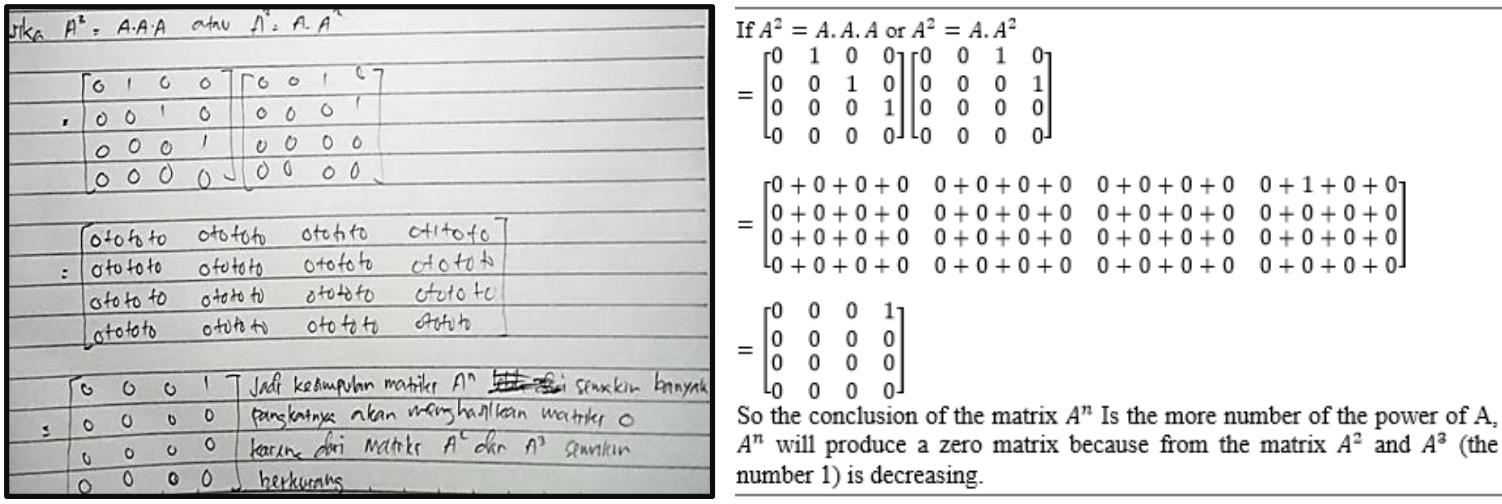

So the conclusion of the matrix $A^{n}$ Is the more number of the power of $A$ $A^{n}$ will produce a zero matrix because from the matrix $A^{2}$ and $A^{3}$ (the number 1 ) is decreasing.

Figure 6. Principle mistakes when writing clear problem-solving ideas

\subsubsection{Mathematical Errors when Expressing Problem Solving Results in His Language}

Students make misconceptions and operational errors when clearly stating the results of solving problems. The mistake made by students when reporting the results of solving the problem was that the multiplication matrix did not recognize ranks so that $\mathrm{A}^{\mathrm{n}}$ could not be a zero matrix. In Figure 7 showed that students wrote that $A^{n}$ could not be a null matrix because matrix A is not a zero matrix.

Matrix operation does not recognize the power form. The power referred to in matrix operation is the repeated multiplication of a matrix with the matrix itself. The condition of a matrix to be raised is that it must be a square matrix or a square matrix. Thus, the exponent of the square matrix itself is the sum of the powers. if the matrix is nonzero, then $A^{n}$ is unlikely to produce a null matrix later. For example number 1 , if number $1^{n}$ then whatever $n$ will not change from 1 to 0 .

Figure 7. Misconceptions when expressing problem solving results in his language

Operation errors made by students when stating the results of solving the problem in the first problem are wrong to conclude that $\mathrm{AC}=\mathrm{BC}$. Students get the same results, but the calculations that have been done are not correct. In Figure 8, students state that the results of problem-solving do not match the calculations obtained.

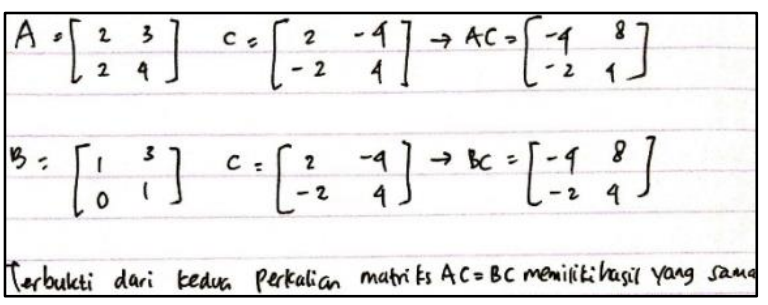

$$
\begin{aligned}
& A=\left[\begin{array}{ll}
2 & 3 \\
2 & 4
\end{array}\right] C=\left[\begin{array}{cc}
2 & -4 \\
-2 & 4
\end{array}\right] \rightarrow A C=\left[\begin{array}{ll}
-4 & 8 \\
-2 & 4
\end{array}\right] \\
& B=\left[\begin{array}{ll}
1 & 3 \\
0 & 1
\end{array}\right] C=\left[\begin{array}{cc}
2 & -4 \\
-2 & 4
\end{array}\right] \rightarrow B C=\left[\begin{array}{ll}
-4 & 8 \\
-2 & 4
\end{array}\right] \\
& \text { It proved that the both multiplication (above), the } \\
& \text { matrix } A C=B C \text { have the same result. }
\end{aligned}
$$

Figure 8. Operating errors when stating problem-solving results in his language 


\subsection{Discussion}

The data of Figure 1 and Figure 2 show that the student's mathematics communication ability was needed to be increased. This finding was in line with Firdaus and Aini (2019) research, which found that students' communication is still in the low category. This research also shows that most students did not fulfill the three indicators of mathematics communication, which indicated their mathematics communication skills need to be improved. Firdaus and Aini (2019) also found that students' weakness in mathematics communication can be caused by student mathematics communication indicators that have not been achieved. Moreover, Syafina and Pujiastuti (2020) found that only students with good mathematics ability can fulfill all mathematics communication indicators. This research found that students' ability to state the problem-solving results using their language is the most difficult mathematics communication indicator for students to fulfill. Students' answers do not give reasons with their language style, so it does not state the conclusions of the given problem. This phenomenon is also found in Mirna's (2018) research. Besides, some students still have difficulty writing ideas and knowing the mathematical situation clearly. So that in this study, students made mistakes in concepts, principles, and operations. Students' types of errors are in line with Zulfah's (2017) research that students make mistakes in the form of concept, process, and principles errors.

Student's mistakes influenced the ability of mathematic communication measurement in each indicator. In other words, mathematics communication ability related each other with students' mistakes (Zulfah, 2017). Afifah et al. (2018), in their research, stated that the types of mistakes made by students were concept errors, operation errors, and principles errors. Firdaus (2019) research shows that in solving the Matrix Problem, the type of error made is concept and operation error. Likewise, with this study that students also carried out misconceptions and operations. More specifics, based on Table 3, most students made conceptual mistakes while solving the problems given. This finding can be considered to point out that students may not be able to communicate their idea well because they did not understand the problem. This possibility inline with Abidin et al. (2017) research concluded that a misconception caused another five kinds of students' mistakes. These conceptual mistakes also affect principles mistakes of student's work (Mirna, 2018). For example, in Figure 4, students' misconception about the definition of identity matrix then applied this wrong idea to analyze the situation. Albeit a little, students also make procedural mistakes when they calculate or simplify the algebra form. Students also found this mistake in Parwati and Suharta (2020) research that procedural mistakes are still made frequently by students when solving algebra problems.

\section{CONCLUSION}

Students' mathematics communication errors in completing HOTS problem on matrix material are concept errors, principles errors, and operating errors. These errors can occur in every student mathematics communication indicator. In the first mathematics communication indicator that understands the mathematical situation clearly, mistakes made are concept errors and operating errors. The second indicator of mathematics communication is writing ideas clearly; the mistakes made are concept errors and principles mistakes. As for the third mathematics communication indicator that states the problem-solving results using their language, the mistakes made are concept errors and operating errors. 


\section{REFERENCES}

Abidin, S. N. Z., Zain, S. M. M., Hamzah, H. H. M., \& Abd Rahim, N. Z. (2017). Misconceptions in solving system of linear. Journal of Global Business and Social Entrepreneurship (GBSE), 1(2), 11-19.

Afifah, D. S. N., Nafi'an, M. I., \& Putri, I. M. (2018). Analisis kesalahan mahasiswa dalam menyelesaikan soal kalkulus peubah banyak. MaPan: Jurnal Matrmatika dan Pembelajaran, 6(2), 207-220. https://doi.org/10.24252/mapan.2018v6n2a7

Angraini, L. M. (2019). The influence of concept attainment model in mathematical communication ability at the university students. Infinity Journal, 8(2), 189-198. https://doi.org/10.22460/infinity.v8i2.p189-198

Ardiawan, Y. (2015). Analisis kesalahan mahasiswa dalam menyelesaikan soal induksi matematika di IKIP PGRI Pontianak. Jurnal Pendidikan Informatika Dan Sains, 4(1), 147-163.

Ardina, F. R., \& Sa'dijah, C. (2016). Analisis lembar kerja siswa dalam meningkatkan komunikasi matematis tulis siswa. Jurnal Pendidikan: Teori, Penelitian, dan Pengembangan, 1(2), 171-180.

Argarini, D. F., Yazidah, N. I., \& Kurniawati, A. (2020). The construction learning media and level of students' mathematical communication ability. Infinity Journal, 9(1), 114. https://doi.org/10.22460/infinity.v9i1.p1-14

Astuti, A., \& Leonard, L. (2015). Peran kemampuan komunikasi matematika terhadap prestasi belajar matematika siswa. Formatif: Jurnal Ilmiah Pendidikan MIPA, 2(2), 102-110. https://doi.org/10.30998/formatif.v2i2.91

Astuty, K. Y., \& Wijayanti, P. (2013). Analisis kesalahan siswa kelas V dalam menyelesaikan soal matematika pada materi pecahan di SDN Medokan Semampir I/259 Surabaya. MATHEdunesa, 2(3), 1-7.

Asviangga, A. B., Sunardi, S., \& Trapsilasiwi, D. (2018). Analisis kemampuan 4C's siswa dalam menyelesaikan soal matematika berpikir tingkat tinggi. KadikmA, 9(1), 17-23.

Fatimah, F. (2012). Kemampuan komunikasi matematis dan pemecahan masalah melalui problem based-learning. Jurnal Penelitian dan Evaluasi Pendidikan, 16(1), 249-259. https://doi.org/10.21831/pep.v16i1.1116

Firdaus, F. (2019). Analisis kesalahan mahasiswa dalam menyelesaikan soal aljabar linier pada materi matriks. Jurnal InTent: Jurnal Industri dan Teknologi Terpadu, 2(1), 4552.

Firdaus, M. F., \& Aini, I. N. (2019). Analisis kemampuan komunikasi matematis siswa SMP pada materi segitiga dan segiempat. Prosiding Seminar Nasional Matematika dan Pendidikan Matematika Sesiomadika 2019, 2(1b), 529-537.

Kleden, M. A. (2016). Kemampuan komunikasi matematis dan self-directed learning mahasiswa. Delta-Pi: Jurnal Matematika dan Pendidikan Matematika, 2(2), 14-20.

Mirna, M. (2018). Errors analysis of students in mathematics department to learn plane geometry. IOP Conference Series: Materials Science and Engineering, 335(1), 012116. https://doi.org/10.1088/1757-899X/335/1/012116

Novianti, D. E. (2017). Profil pemecahan masalah matematika dalam menyelesaikan permasalahan pemrograman linear ditinjau dari kemampuan komunikasi matematis 
mahasiswa. JIPM (Jurnal Ilmiah Pendidikan Matematika), 6(1), 53-59. https://doi.org/10.25273/jipm.v6i1.1698

Nuraida, I., \& Amam, A. (2019). Hypothetical learning trajectory in realistic mathematics education to improve the mathematical communication of junior high school students. Infinity Journal, $8(2), \quad$ 247-258. https://doi.org/10.22460/infinity.v8i2.p247-258

Parwati, N., \& Suharta, I. (2020). Effectiveness of the implementation of cognitive conflict strategy assisted by e-service learning to reduce students' mathematical misconceptions. International Journal of Emerging Technologies in Learning (iJET), 15(11), 102-118. https://doi.org/10.3991/IJET.V15I11.11802

Prabawanto, S. (2019). Enhancement of students'mathematical communication under metacognitive scaffolding approach. Infinity Journal, 8(2), 117-128. https://doi.org/10.22460/infinity.v8i2.p117-128

Pratiwi, D. D. (2015). Analisis kemampuan komunikasi matematis dalam pemecahan masalah matematika sesuai dengan gaya kognitif dan gender. Al-Jabar: Jurnal Pendidikan Matematika, 6(2), 131-142.

Pratiwi, P. H., Hidayah, N., \& Martiana, A. (2017). Pengembangan modul mata kuliah penilaian pembelajaran sosiologi berorientasi HOTS. Cakrawala Pendidikan, 36(2), 201-209. https://doi.org/10.21831/cp.v36i2.13123

Rahayuningsih, S., \& Jayanti, R. (2019). High order thinking skills (HOTS) mahasiswa program studi pendidikan matematika dalam menyelesaikan masalah grup. MAJAMATH: Jurnal Matematika dan Pendidikan Matematika, 2(2), 87-93.

Rosita, C. D., Nopriana, T., \& Silvia, I. (2019). Design of learning materials on circle based on mathematical communication. Infinity Journal, 8(1), 87-98. https://doi.org/10.22460/infinity.v8i1.p87-98

Ruswana, A. M. (2019). Analisis kemampuan pemahaman matematis pada mata kuliah aljabar linier elementer. Jurnal Cendekia: Jurnal Pendidikan Matematika, 3(2), 293299. https://doi.org/10.31004/cendekia.v3i2.111

Subekti, F. E., Untarti, R., \& Gunawan, G. (2016). Identifikasi kesalahan jawaban mahasiswa ditinjau dari kemampuan komunikasi matematis. Jurnal Edukasi dan Sains Matematika (JES-MAT), 2(2), 41-52. https://doi.org/10.25134/jesmat.v2i2.346

Syafina, V., \& Pujiastuti, H. (2020). Analisis kemampuan komunikasi matematis siswa pada materi SPLDV. MAJU: Jurnal Ilmiah Pendidikan Matematika, 7(2), 118-125.

Umar, W. (2012). Membangun kemampuan komunikasi matematis dalam pembelajaran matematika. Infinity Journal, 1(1), 1-9. https://doi.org/10.22460/infinity.v1i1.2

Widodo, S. A. (2013). Analisis kesalahan dalam pemecahan masalah divergensi tipe membuktikan pada mahasiswa matematika. Jurnal pendidikan dan pengajaran, 46(2), 106-113.

Widodo, S. A., Irfan, M., Trisniawati, T., Hidayat, W., Perbowo, K. S., Noto, M. S., \& Prahmana, R. C. I. (2020). Process of algebra problem-solving in formal student. Journal of Physics: Conference Series, 1657(1), 012092. https://doi.org/10.1088/1742-6596/1657/1/012092 
Wijaya, A. A., \& Masriyah. (2013). Analisis kesalahan siswa dalam menyelesaikan soal cerita materi sistem persamaan linear dua variabel. MATHEdunesa, 2(1).

Zukhrufurrohmah, Z., \& Kusumawardana, A. S. (2019). Analisis Kesalahan Matematis Mahasiswa Teknik Sipil pada Mata Kuliah Kalkulus II. Jurnal Review Pembelajaran Matematika, 4(1), 1-10. https://doi.org/10.15642/jrpm.2019.4.1.1-10

Zulfah, Z. (2017). Analisis kesalahan peserta didik pada materi persamaan linear dua variabel di kelas VIII mts negeri sungai tonang. Jurnal Cendekia: Jurnal Pendidikan Matematika, 1(1), 12-16. 